Ogbonnaya Ukeh Oteh,

Ph.D., Michael Okpara University of Agriculture Umudike, Nigeria

(iD) ORCID ID, 0000-0001-9561-6294

email: ogboteh@gmail.com

Ambrose Ogbonna Oloveze,

Michael Okpara University of Agriculture Umudike, Nigeria

(iD) ORCID ID, 0000-0003-0320-9793

email: emrysoloveze@gmail.com

Raymond Ozoemena Obasi,

Ph.D., Michael Okpara University of Agriculture Umudike, Nigeria

email: rayobasi@gmail.com

J. O. Opara,

B.Sc., Michael Okpara University of Agriculture Umudike, Nigeria

email: jerry.chuks@yahoo.com

Correspondence author: ogboteh@gmail.com

\title{
CONSUMER HEALTH KNOWLEDGE: CULTURAL NORMS AND MARKETING OF HEALTHCARE PRODUCTS
}

Abstract. This paper discourses healthcare products that face some degree of acceptance within some societies due to specific cultural dilemmas and ethical concerns. The purpose of this paper is to assess consumer health knowledge on the cultural and ethical dilemma and norms as they affect the marketing of healthcare products. Literary sources indicate the existence of misconceptions and poor marketing performance of healthcare products within a cultural milieu in Nigeria, thus the focus is on indigenous people and their cultural backgrounds. To gain insight into consumer health knowledge, the study modelled Hofstede's collectivism dimension following the dominant in-group cultural context of the indigenous people. The relevance of this scientific decision problem is that the result will cause an urgent policy approach, re-strategizing of approaches in communication and reach by the healthcare marketers and healthcare product producers. The research follows a survey pattern as data was collected for $4-5$ months in year 2020 using a structured questionnaire while mean rating analysis and Pearson Coefficient correlation were used to analyze the result. The object of this research was Abia State in Nigeria, given that good numbers of the communities are notorious for the patronage of traditional healthcare products. The results proved that negligence of immunization, dependence on traditional health healers, and maintenance of ethical work environment are critical concerns that impact consumers' health knowledge and their response to healthcare products being marketed by firms. Thus, the research makes an empirical confirmation and theoretically proves that Hofstede's collectivism dimension appropriately profiles the dominant in-group cultural context of the indigenous people of Abia State, Nigeria. The findings of this research show its practical usefulness by identifying the need for communication, enlightenment and awareness programs, and practical demands for strategic approaches to marketing healthcare products within the communities. Policy-wise, the implication is the urgent demand to moderate beliefs and norms of the group by devising stringent measures for clinical laboratory tests of the traditional drugs and stiff penalties for defaulters of traditional healthcare product vendors and producers.

Keywords: collectivism, consumer health knowledge, cultural dilemma, ethical norms, healthcare products, marketing.

Introduction. Consumers today are exposed to a wide range of influences (Sama, 2019; Boca, 2021). The influence can come within society, which shapes consumers' attitude towards product usage (Nguyen et al., 2019). In the present world, culture is one of the most important determinants of choice when

Cite as: Oteh, O. U., Oloveze, A. O., Obasi, R. O., \& Opara, J. O. (2021). Consumer Health Knowledge: Cultural Norms and Marketing of Healthcare Products. Health Economics and Management Review, 1, 8-22. http://doi.org/10.21272/hem.2021.1-01

Received: 20 January 2021 

Healthcare Products

purchasing products or services. It can influence an individual's interaction with a product and purchasing behaviour (Ali and Sudan, 2018; Ajima and Ubana, 2018). This is because culture is often the foundation of peoples' beliefs, habit, traditions, behavioral elements, different feeding ways, and perceptions with respect to their surroundings. In this guise culture can be seen as a collective programming of the mind that creates observable differences between two or more group of people (Bissessar, 2018; Hofstede, 2011). This implies that indigenous people bounded by same culture often share common elements like religion, belief, language, opinions and learning experiences about healthcare. The elements are commonly influenced by socio-cultural contexts such that indigenous healers are perceived as alternative healthcare especially when they are considered as solution to certain health issues (Kaihlanen et al., 2019; Peprah et al., 2018). This also pervades into families such that they do not accept vaccination (Faasse and Newby, 2020) and consequently conceive vaccination as being unsafe and risky following perceived fears thereby causing ethical dilemmas (Hussain et al., 2018). In other cases, peoples' religious beliefs tend to influence health care services and products (Pfeiffer et al., 2018; Heward-Mills et al., 2018; Asakitikpi, 2019) to such extent that they believe that western trained doctors do not have the appropriate skills and training to address the peculiarity of their physical and spiritual health issues. This is because of the earlier dependence on traditional medicine by the indigenous people (Asakitikpi, 2019). People have certain negative reactions to orthodox healthcare in that its drugs cannot effectively cure diseases (Krah et al., 2018) whereas traditional healthcare services are considered to be potency proof and effective despite its unrefined methods of preparation and application which needs refinement (Ameade et al., 2018; Salim et al., 2018; Mothibe and Sibanda, 2018).

In recent times, there have been clear indications that cultural effects on healthcare have been important (Ajima and Ubana, 2018). The importance is highlighted by the increase in mortality rate in Nigeria within 2007 and 2011. Reports of National Bureau of Statistics (2011) and World Bank (2013) indicate there was an increase in under-five mortality in Nigeria from 138 per 1000 live births in 2007 to 158 per 1000 live births in 2011. This could stem from ethical issues in drug production given the increased prevalence of fake drugs as WHO (2005) asserts there is about $30 \%$ fake drugs in Nigeria. This is a significant public health problem that has taken a global shape (Klantschnig and Huang, 2019). On the other hand, non-recognition of indigenous ill-health beliefs and local medicinal knowledge in healthcare by biomedical healthcare institutions in developing nations is a cause for concern (Kahissay et al., 2017; Mordeniz, 2019). Biomedical healthcare institutions often consider them to be harmful, non-beneficial and threatening to human health. Despite the biomedical healthcare institutions' position, indigenous people still patronize indigenous healthcare system as an alternative healthcare service though it is in conjunction with biomedical healthcare services (Salim et al., 2018; Mothibe and Sibanda, 2018). The import of this non symmetry of orthodox versus traditional medicine should have a defining role on the marketing of healthcare products. This is because studies suggest that different societies accord varying levels of importance to natural causes of ill-health against spiritual causes (Kahissay et al. 2017; Odwe et al., 2020; Kahissay et al., 2020). Particularly patronage levels of healthcare products can show variations in consumers' preference and choice of a healthcare product as there is observed high patronage in rural areas given high mortality rate in the area (Asakitikpi, 2019), and low income earners in urban areas (Silas et al., 2015; Asakitikpi, 2019).

Accordingly, the application of marketing programmes is not dissimilar in marketing of healthcare products. Applying marketing in healthcare involves identifying current and prospective patients' needs, understanding their perceptions and offering solutions that will deliver desired effect to them. Studies indicate that marketing can produce significant influences when applied in healthcare (Purcarea, 2019; Bairagdar et al., 2021; Liao, 2020). As such the study underpins this as it attempts to assess consumer health knowledge given the growing burden of marketing of healthcare products within the context of 
cultural norms and beliefs and its associated prevalent unethical practices in consumer health knowledge. In essence the study seeks to:

1. Determine factors that influence cultural beliefs and norms in marketing of healthcare products.

2. Ascertain how cultural and ethical dilemmas affect marketing of healthcare products.

3. Examine the influence of cultural beliefs on sales volume of healthcare products.

Literature Review. Culture is the main foundation that controls people's activities, conduct of their lives and norms (Khan and Law, 2018). It is sometimes seen as an orientation system (Verboord and Nørgaard Kristensen, 2020), collective programming of the mind (Hofstede, 2011) or complex capabilities that covers knowledge, belief, art, law, morals, customs and habits acquired by members of a society (Papazoglou, 2019). Whether as an orientation system, software of the mind, or complex capabilities acquired by members of a society, consumers tend to be influenced by what is passed on to them as well as the influences the norms of the society they live in have on their buying behavior. The values and beliefs naturally define this influence in the society (Khan \& Law, 2018) while these aspects of the society guides behavior and transmits direct and indirect messages about selection of goods and service to consumers (Liu and Segev, 2017; Popovic et al., 2019). Consumer preferences and consumer decision making on products may largely differ as a result of bias projected by culture. Consumers can be attracted to a product or service when there is symmetry between the product they are attracted to and consumer's customs, traditions, norms and cultural requirements. In other words cultural sensitivity is a prerequisite in achieving changes in health matters (Latif, 2020). In other cases cultural factors might pose difficult challenges due to lack of symmetry between healthcare professionals and the patients to such extent that effectiveness and satisfactory healthcare is inhibited. In essence, consumers are as well associated with asymmetry wherein they draw comparison of their own culture, self-concept and product associations (Bettels and Wiedmann, 2019). The symmetry concerns in culture thus present a sizeable challenge in marketing of healthcare products. This arises from the reasoning that culture shapes the way and how people behave in any given society (Paudel et al., 2018). This is buttressed further by Popovic et al. (2019) and AkosahTwumasi et al., (2018) such that cultural factors like traditions, customs, beliefs and attitudes of people produce large influence on people's needs, wants and how they are satisfied. These factors present daily challenge to primary healthcare (Dahia and Chima, 2017) especially where there is lack of culturally sensitive programmes (Seshan et al., 2018) and non-compliance that has its roots in cultural factors. Ordinarily, cultural values are enduring beliefs that a specific mode of conduct is preferred to the opposite mode of conduct (Rokeach, 1973; Prinsloo and Lew, 2021). The beliefs are regarded as ideas and thoughts common to several individuals that govern interaction which become identical and commonly known through the socialisation process by which culture is unified, maintained and communicated (Hédoin, 2021; Greif, 2006). People who hold certain cultural health beliefs and values in a society have different thoughts and feelings about their health (European Health Report, 2018; Fadyl, 2021) and sticking to therapeutic regimes if often affected by their cultural belief and severity of the disease (Shahin et al., 2019). In essence, any difference in cultural factor will influence an individual's perception of symptoms and emotional state and as well shape ability to understand physician's instructions. It is on this guise that individuals develop preference for products, and have specific dilemmas about products.

In theory, Hofstede (2011) posit a dimension of culture from individualistic and collectivism perspective. In individualistic culture the «l» takes precedence in that the interest of the individual prevails over the interest of the group (Hofstede et al., 2010). Consumers controlled by this culture often act as individuals with self-control (Li et al., 2018), and rarely are controlled by the family, society or any other ingroup (Hofstede et al., 2010) on buying behaviour. This is why in individualistic cultures there may be the tendency of an individual not to rely on the influence from the family, or society on product purchases but may have to cleave to what aligns to personal identity. This is because their personal identity is at variance with other people «|»s and as such is classified according to individual characteristics than group 

Healthcare Products

membership (Hofstede et al., 2010). On the other hand, collectivism culture goes by «We» in that the interest of the in-group or society the individual lives prevails over the interest of the individual (Hofstede et al., 2010). Buying behaviour of individuals in collectivism culture may be influenced by the family unit, society, relatives, and any other in-group within the individual's life. Specifically, the decisions of the ingroup can have profound effect on the individual's product choice and preference. In this scenario, specific marketing communications and advertisements on health products may produce general effect on the public because it was deemed to be acceptable by health personnel, family unit, the society or the government. Each society have distinct peculiar practices that have deep influence on the perception, attitudes and behaviour of people in managing diseases and health related problems that befall them. Hypothetically, poor understanding of the prevailing cultural dimension (individualistic versus collectivism) by the marketer should have a meaningful impact on marketing programmes designed to address health related issues. This is where misconceptions about orthodox effective treatment and drugs' side effects domicile. This is more related in cases where societal belief condition serious illness as having supernatural connotation (Hernandez and Gibb, 2020) that can only be treated using traditional medicine. The salient belief is to resort to orthodox or traditional medicine depends on the severity of the ailment, perceived causes of ailment, and goal to stay healthy (Afolabi et al., 2020). However, there are cases when the society takes causes of illnesses as secondary while supernatural (spiritual) cause is primary (Afolabi et al. 2020; Ojua et al., 2013). Generally, the individualistic culture and collectivism culture affect consumers' choice of product and subsequent purchases (Kaur and Chawla, 2016). Understanding the prevailing one in the society should serve as meaningful guide to marketer in planning marketing programmes around healthcare products. One of the key issues addressed in the individualistic/collectivism dimension is how a society manages inequalities when they occur (Hofstede, 2011). This reflects often on values within the society, choice of product and purchases. Particularly, cultural influences on buying behaviour are to the extent that consumers often display these influences in the values they pick from the society (Fahimeh et al., 2016). Such cultural values affect marketing decisions on the marketing mix elements (Castro and Sáiz, 2020). However, many people in this world live within societies in which group's interest takes precedence and interest over individuals interest (Hofstede et al., 2010). Nigerian culture though being multi-dimensional still revolves largely on collectivism culture than individualistic culture in some communities compared to others. The communities under study in Nigeria largely possess elements of collectivism. Individuals' behaviour within the study area is largely influenced by family units and societal nous.

Notably, products and services are reflective of cultures (Fahimeh et al., 2016) and marketers try to align with the cultural waves than going against them (Song et al., 2017). This is because of the deep influence culture has on consumer's choice of product, motivation, and lifestyle which is clearly shown by the size of their preference for same products (Kaur and Chawla, 2016). Consumers tend to express themselves through a cultural symbol rather than deriving benefits from them (Fahimeh et al., 2016). They often display negative reactions in culture mixing when their attention is drawn to the implications of marketing practice for the purity and integrity of sacred cultural tradition. In present times, marketing strategies are consistently being adopted by healthcare providers due to competition and changing needs of patients (Purcarea, 2019; Ekiyor and Altan, 2020). Marketers cannot ignore the analysis of the prevailing culture before selling their products in the market given that they need to create customer awareness regarding the features of their product before influencing the customers to purchase the products (Kaur and Chawla, 2016). In essence, what consumers purchase and why, how, when, where and from whom they purchase a product is influenced by culture (Singh et al., 2020; Paudel et al., 2020). In this regard, culture is deemed to impact every aspect of marketing strategy (Kaur and Chawla, 2016; Purcarea, 2019; Ekiyor and Altan, 2020). The application of the concepts of marketing in healthcare on the other hand is paramount considering the health challenges of the society (Purcarea, 2019) as the cultural factors play 

Healthcare Products

significant role on healthcare products marketability (Song et al., 2017). In this regard, evidence from extant literature shows that sometimes consumers express themselves through symbols (Fahimeh, et al. 2016; Kaur and Chawla, 2016). As a result marketers tap into this through their efforts to establish symbols that introduce products that have positive cultural values (Khan and Law, 2018).

Ethics are often considered to be science of studying morality (Figar and Dordevic, 2016) and rules of moral values that is very helpful in making decisions (Tamunomiebi, and Ehior, 2019). It deals with human values, rights, duties and moral principles of behavior (Stokhof, 2018). In marketing, bulk of the studies is on ethical consumption phenomenon (Sorum, 2020) as it focuses on absolute good and values as well as principles and standards that define acceptable conduct (Stokhof, 2018). In other words, ethical concerns of consumers affect their consumption behaviour (Budhathoki, 2019). Consumers' ethical concerns call for avoidance of unintended consequences of marketing activities given that they show concerns such as trust on the information about the content (Budhathoki, 2019), display of vital and relevant information that concerns the product (Kraus et al., 2017), component materials used in the product (Rana and Paul, 2017) and allergies and tolerances (Asioli et al., 2017). The implication is that both individual marketers and organisations have a part to play in ethical decisions. While ethical codes is exemplified by values (Poorchangizi et al., 2019) individual's personal values and philosophies represent key areas in ethical decisions as they influence behavior (Van Rooij and Fine, 2018) and decision making (Mumley, 2019). On the other hand, codes and training that provide consistent and shared approaches are vital in ethical decisions from marketing firm's perspective. Generally, ethical issues are integral in decision making for a professional (de Graaf, 2019). Ethical decisions from either angle can produce profound effect on marketing as Ofurum and Gabriel (2019) concluded that ethical decisions that lead to unethical practices can produce serious consequences that can result in market failures, financial losses and poor corporate image. While ethical decisions reflect, individuals are sometimes cumbered with ethical dilemmas which invariably put them in situations of making decisions between two good products or two bad products. In other words, ethical dilemma deals with situations that involve making choice between two or more alternatives and the criterion for considering the best choice often differ between individuals (Figar and Dordevic, 2016). The decision on choice often borders between two morally right alternatives and this is significant when it comes to healthcare products. There are different products in the market and consumers often have alternatives to make their choices whenever they are buying products from the market. The choices can be influenced by factors such as perception, behavioural skills and health risk stress (Luo et al., 2020) as well as perceived poor staff competencies and perceived negative attitude of health provider (Ngwenya et al., 2020). The alternative products they have in mind often produce conflicts within them as they always want to make the best choice in the midst of conflicting alternative choices. In most cases when individuals need a trade-off on products, decisions are often difficult though younger adults tend to go for products with better rating (Von Helversen et al., 2018). Besides it is in their effort to make the best choice between conflicting alternatives that dilemma occurs. Usually, it presents an unpleasant situation for the individual (Figar and Dordevic, 2016) which becomes more unpleasant should the individual's need to make a choice become more conflicting. Basically, within every dilemma is an ethical dilemma (Figar and Dordevic, 2016).

Methodology and methods. The study adopted descriptive survey. Primary data and secondary date were used. While questionnaires were used in collecting primary data, the study used journals, articles, textbooks and internet resources for secondary data. The population was chosen to include customers of orthodox and traditional healthcare products. 150 questionnaires were distributed among customers of both orthodox and traditional healthcare products in Abia State. The questionnaire consists of two sections of demographic variables of the customers of healthcare products and cultural factors. After removing 12 altered questionnaires, 138 questionnaires were valid and used for the analysis. 

Healthcare Products

Likert scale was used to measure ethical dilemmas, cultural dilemmas, cultural beliefs and ethical norms. The respondents were asked to rate the items on the list which ranged from $1=$ strongly disagree to $5=$ strongly agree. Face validity and content validity were used to validate the measurement scale. This was done following face-value check and using the contributions of two experts in the area to check the measurement scale. Cronbach Alpha was used to test the internal consistency of items used. The item score indicates 70.5 thereby showing good internal consistency of the scale items. A coefficient of less than 0.6 indicates marginal to low internal consistency and a value of 0.60 or more indicates satisfactory internal consistency reliability (Saidi and Siew, 2019; Gravesande et al., 2019; Kawakami et al., 2020). Mean rating analysis and correlation analysis was adopted in analysis the data collected from the field. The decision criterion for the mean analysis is based on cut-off of $>3.0$ or above to be acceptance of the statements listed above. For correlation analysis, the analysis is based on Pearson Correlation coefficient. The formula is given as:

$$
r=\frac{N_{x y}-\left(\sum x\right)\left(\sum y\right)}{\sqrt{\left[N \sum(x)^{2}-\left(\sum x\right)^{2}\right]\left[N(y)^{2}-\left(\sum y\right)^{2}\right]}}
$$

Given a priori expectation, the correlation coefficient is expected to be: $r>0$

where: $r=$ Pearson product moment correlation coefficient; $X=$ Cultural belief Practices/ethical norms; $\mathrm{Y}=$ Sales volume of healthcare products; $\mathrm{N}=$ Sample size; $\Sigma=$ Summation sign.

Results. The response rate is about $92 \%$ and this was deemed acceptable to use in the study. A questionnaire response rate that ranges between $50-70 \%$ is considered adequate for research (Saunders, Lewis, \& Thornhill, 2009; Hair, Black, Babin, Anderson, \& Tatham, 2006; Oloveze, Oteh, Nwosu, \& Obasi, 2021). About $55 \%$ of the respondents surveyed were aged between 18 and 30 years. $53 \%$ of the respondents were female and $68 \%$ were married. Most of them ranging about $87 \%$ had tertiary education while greater number of them (about 92\%) was Christians.

Table 1. Various cultural and ethical dilemmas with marketing of healthcare product

\begin{tabular}{|c|c|c|c|c|c|c|}
\hline Variables & $\begin{array}{l}\text { Strongly } \\
\text { Agree }\end{array}$ & Agree & Undecided & Disagree & $\begin{array}{l}\text { Strongly } \\
\text { Disagree }\end{array}$ & Mean \\
\hline \multicolumn{7}{|l|}{ Cultural dilemmas } \\
\hline Negligence of Immunization & 34.6 & 50.7 & 10.3 & 4.4 & & 4.15 \\
\hline $\begin{array}{l}\text { Dependence on traditional } \\
\text { health healers }\end{array}$ & 24.3 & 55.9 & 17.6 & .7 & 1.5 & 4.01 \\
\hline $\begin{array}{l}\text { Rejection of western medicine } \\
\text { (orthodox) }\end{array}$ & 20.6 & 48.5 & 16.9 & 14.0 & & 3.76 \\
\hline Family spiritual beliefs & 10.4 & 62.7 & 19.4 & 7.5 & & 3.76 \\
\hline $\begin{array}{l}\text { Lack of openness to questions } \\
\text { from healthcare practitioners }\end{array}$ & 11.8 & 51.5 & 28.7 & 8.1 & & 3.67 \\
\hline Perception of illness & 11.8 & 43.3 & 27.9 & 11.0 & & 3.62 \\
\hline $\begin{array}{l}\text { Influence of family dynamics } \\
\text { (Gender role, pattern among } \\
\text { families }\end{array}$ & 11.0 & 54.4 & 22.8 & 10.3 & 1.5 & 3.63 \\
\hline $\begin{array}{c}\text { Willingness to discuss } \\
\text { symptoms with health provider }\end{array}$ & 5.1 & 70.6 & 19.9 & 2.7 & 1.5 & 3.75 \\
\hline $\begin{array}{l}\text { Access to needed healthcare } \\
\text { resources for the aged, } \\
\text { chronically ill and mentally ill }\end{array}$ & 21.3 & 41.2 & 24.3 & 13.2 & & 3.71 \\
\hline
\end{tabular}


O. U., Oteh, A. O., Oloveze, R. O., Obasi, J. O., Opara. Consumer Health Knowledge: Cultural Norms and Marketing of Healthcare Products

\begin{tabular}{|c|c|c|c|c|c|c|}
\hline $\begin{array}{l}\text { Conflict of interest between } \\
\text { health practitioners }\end{array}$ & 14.7 & 58.4 & 16.02 & 11.0 & & 3.76 \\
\hline Moral distress and resilience & 30.9 & 51.5 & 22.4 & 4.4 & & 3.71 \\
\hline $\begin{array}{c}\text { Maintaining ethical work } \\
\text { environment }\end{array}$ & 17.6 & 50.0 & 17.6 & 1.5 & & 4.10 \\
\hline $\begin{array}{l}\text { Incompetence among workers } \\
\text { (health providers) }\end{array}$ & 4.4 & 46.3 & 29.4 & 6.6 & & 3.75 \\
\hline Telemedicine & 8.8 & 38.5 & 53.7 & 5.1 & 1.5 & 3.36 \\
\hline $\begin{array}{l}\text { Treating disadvantaged } \\
\text { patients (poor) }\end{array}$ & 10.3 & 54.4 & 22.1 & 14.7 & & 3.57 \\
\hline Physician-assisted deaths & 10.3 & 36.8 & 33.8 & 15.4 & 3.7 & 3.35 \\
\hline $\begin{array}{l}\text { Wrestling with equal treatment } \\
\text { to average patients vs VIP } \\
\text { treatment to donors and } \\
\text { influential individuals }\end{array}$ & 12.5 & 50.0 & 30.1 & 2.2 & 5.1 & 3.63 \\
\hline
\end{tabular}

The decision criteria for the mean analysis imply that values of 3.0 and above have positive response and acceptance to the statements in the measurement scale. Nine (9) items were used to measure cultural dilemmas. The structured items captured family influence, belief and medical dynamics. Generally, all the items were above 3.0. The implication is that the measurement items on cultural dilemma were all true in their respective effects on marketing of healthcare products. Specifically, dilemmas on negligence of immunisation as well as dependence on traditional health healers are mostly considered to have the most cultural dilemma associated with marketing of healthcare products. This follows the high mean scores of 4.15 and 4.01 respectively compared to the mean scores of the other cultural dilemmas.

Ethical dilemmas were structured with 8 items. All the scale items that was measured using mean rating analysis indicates positive responses to the dilemmas having an influence on marketing of healthcare products. This is because all the scale items were greater than 3.0 which are the decision criteria. However, maintaining ethical work environment has the highest mean rating of 4.10. By this result, the item is shown to be the most important ethical dilemma associated with marketing of healthcare products.

Table 2. Ethical norms on healthcare products

\begin{tabular}{|c|c|c|c|c|c|c|}
\hline Variables & $\begin{array}{l}\text { Strongly } \\
\text { Agree }\end{array}$ & Agree & Undecided & Disagree & $\begin{array}{l}\text { Strongly } \\
\text { Disagree }\end{array}$ & Mean \\
\hline \multicolumn{7}{|l|}{ Product: } \\
\hline Mislabelling of healthcare products & 40.6 & 55.1 & 2.9 & 1.4 & & 4.35 \\
\hline Counterfeit healthcare products & 31.2 & 64.5 & 4.3 & & & 4.27 \\
\hline Unregistered healthcare products & 29.0 & 59.4 & 7.2 & 4.3 & & 4.13 \\
\hline \multicolumn{7}{|l|}{ Pricing: } \\
\hline Price discrimination & 30.4 & 39.1 & 29.0 & 1.4 & & 3.49 \\
\hline Unfair credit practices & 11.6 & 56.5 & 26.1 & 5.8 & & 3.74 \\
\hline $\begin{array}{l}\text { Excessive mark-up } \\
\text { Price }\end{array}$ & 17.4 & 43.5 & 36.2 & 2.9 & & 7.54 \\
\hline \multicolumn{7}{|l|}{ Promotion: } \\
\hline $\begin{array}{l}\text { Information and disclosure of } \\
\text { healthcare product }\end{array}$ & 24.6 & 53.6 & 18.8 & 1.4 & 1.4 & 3.99 \\
\hline
\end{tabular}


O. U., Oteh, A. O., Oloveze, R. O., Obasi, J. O., Opara. Consumer Health Knowledge: Cultural Norms and Marketing of Healthcare Products

\begin{tabular}{llllccc} 
& \multicolumn{1}{c}{} & & & \multicolumn{2}{c}{ Continued Table 2 } \\
\hline $\begin{array}{l}\text { General honesty and integrity of } \\
\text { healthcare products }\end{array}$ & 21.7 & 59.4 & 15.9 & 2.9 & & 4.00 \\
\hline Place: & & & & & & \\
\hline Hoarding of products & 17.460 .9 & 49.3 & 26.1 & 5.8 & 1.4 & 3.75 \\
\hline Illegal importation & 29.0 & 60.0 & 10.1 & & & 4.19 \\
\hline
\end{tabular}

Sources: developed by the authors.

Ethical norms on healthcare products were structured around product, pricing, promotion and place. Ethical norms on product and pricing were measured using 3 items while ethical norms on promotion and place were measured using 2 scale items. Ethical norms on product items in the scale shows that mislabelling of healthcare products, counterfeit healthcare products and unregistered healthcare products have ethical concerns. The mean scores were greater than 3.0. Equally, all the mean scores ranging between 4.13 to 4.35 clearly indicates that there is a strong connection between consumers and mislabelling of healthcare products, counterfeit healthcare products and unregistered healthcare products. However, the major item considered as affecting standardised conduct and behaviour in marketing of healthcare products is mislabelling of healthcare products. The mean score is highest at 4.35 .

Going by the result from ethical norms on pricing; price discrimination, unfair credit practices and excessive mark-up price had mean scores that is greater than 3.0. By this result, the items on the scale for ethical norms on pricing are seen as affecting acceptable conduct in marketing of healthcare products. The major item considered essential in affecting acceptable conduct of healthcare products is excessive mark-up price charged on healthcare products. This follows its highest mean score of 7.54. Ethical norms on promotion and place were structured on two items each in the scale. While the respective results indicate that the statements were true of affecting standardised conduct and behavior in marketing healthcare products given their $>3.0$ mean score, general honesty and integrity of healthcare products, and illegal importation were the primary concerns from promotion and place respectively. This follows their respective high mean scores of 4.00 and 4.19 respectively.

Table 3. Cultural and ethical factors that affects marketing of healthcare products

\begin{tabular}{ccccccc}
\hline Variables & $\begin{array}{c}\text { Strongly } \\
\text { Agree }\end{array}$ & Agree & Undecided & Disagree & $\begin{array}{c}\text { Strongly } \\
\text { Disagree }\end{array}$ & Mean \\
\hline Cultural factors: & & & & & & \\
\hline Education and formal learning & 44.2 & 44.3 & 6.5 & & 3.38 \\
\hline Opinions & 24.6 & 52.9 & 15.2 & 7.2 & 3.95 \\
\hline Learning experiences & 17.4 & 58.0 & 21.7 & 2.9 & 3.90 \\
\hline Gender & 21.0 & 35.5 & 24.6 & 18.8 & 3.59 \\
\hline Food and dietary beliefs & 20.3 & 48.5 & 21.0 & 13.8 & 3.4 \\
\hline Religion & 28.3 & 43.5 & 19.6 & 8.7 & 3.91 \\
\hline Family setting & 20.3 & 43.5 & 31.9 & 4.3 & & 3.80 \\
\hline Ethical factors: & & & & & 3.75 \\
\hline Confidentiality & 8.7 & 57.2 & 34.1 & & 3.95 \\
\hline Aggressive marketing practices & 22.5 & 22.9 & 23.2 & 1.4 & 3.84 \\
\hline Providing accurate information & 53.6 & 23.2 & 1.4 & 2.9 & & 3.85 \\
\hline Disagreements & 20.3 & 49.3 & 27.5 & 2.9 & & 3.78 \\
\hline Code of conduct & 15.2 & 54.3 & 23.9 & 6.5 & & \\
\hline
\end{tabular}

Sources: developed by the authors. 

Healthcare Products

The result shows cultural factors and ethical factors that affects marketing of healthcare products. Cultural factors were measured using 7 scale items while ethical factors were measured using 5 scale items. Generally, the scale items for both cultural factors and ethical factors were shown to have mean scores above 3.0. Going by the decision criteria, these items are deemed true statements in influencing marketing of healthcare products. Following the differences in mean scores of the cultural factors, educational and formal training are considered to be paramount in affecting marketing of healthcare products following its high mean score of 4.38 . On the other hand, all other items used to measure cultural factors and ethical factors had similar influences on marketing of healthcare products with none having the greatest influence than others.

Table 4. Marketing sales performance (sales volume)

\begin{tabular}{c|c|c}
\hline & Cultural Belief & Sales Volume \\
\hline Cultural Belief Pearson correlation & 1 & .023 \\
Sig. (2-tailed) & 136 & .079 \\
N & .023 & 136 \\
\hline Sales Volume Pearson correlation & .079 & 1 \\
Sig. (2-tailed) & 136 & 136 \\
N & & \\
\hline
\end{tabular}

Sources: developed by the authors.

The result shows there is no significant relationship between cultural belief and sales volume at 2 tailed test.

Conclusion. The aim of this research is to assess the consumer health knowledge in the context of cultural norms that influence marketing of healthcare products with focus on cultural and ethical dilemmas. The study centred on Hofstede's theory of individualism/collectivism with peculiar attention on collectivism given the cultural context of the study unit. Besides, analyses were made between the different cultural contexts and dilemmas as it affects marketing of healthcare products.

First of all, the cultural dilemma which had the highest influence is negligence of immunisation. This is as a result of some cultural factors such as traditional beliefs and the challenges of education and formal learning. Earlier studies show that this can as well be due to traditional beliefs that illnesses are caused by ancestral spirit anger (Worknehet al., 2018; Biswal et al., 2017) as well as disregard to orthodox healthcare facilities due to misconceptions about orthodox effective treatment and drugs' side effects (WHO, 2008). As observed, marketing of healthcare products were deeply affected by the general cultural belief of spiritual causes of sickness but resort to traditional approaches for treatment. This particular approach arises due to slackness, disregard and poor knowledge of the benefits of immunisation because of the societal held belief. The import of this is that beliefs held by indigenous people tend to have effect on health care services and products (Burnett et al., 2020; Asakitikpi, 2019; Pfeiffer et al., 2018; HewardMills et al., 2018). In addition, the prevalent belief of indigenous people about orthodox healthcare is that they are costly and barely affordable considering their economic status. This place the indigenous people in a vulnerable situation that festers their belief that orthodox healthcare is not affordable. This is a pointer to their medical-poverty trap (Oteh et al., 2016) that affects marketing of healthcare products especially within the rural and semi-urban locations.

In the second place, marketing of healthcare products is determined by dependence on traditional health healers. Traditional healthcare system is often the first place indigenous people resort to thereby making orthodox approaches a secondary approach especially when the traditional approach fail to yield expected healing. Traditional health healers often take precedence to orthodox approaches when sicknesses are perceived as spiritual. This finding has been confirmed in several fields and the results here consolidate earlier studies (Ahlberg, 2017; Mothibe and Sibanda, 2018; Aragaw et al., 2020). On the 

Healthcare Products

other hand, the dependence on traditional health healers is promoted by poor financial background of the indigenous people. It is a big challenge in people's access to healthcare facilities in rural communities. Inability of indigenous people to access healthcare conditions them to rely on traditional health healers which are comparatively considered to be cheaper and highly affordable to them. In some cases, it is considered to be more effective compared to orthodox healthcare. As a result indigenous people firstly resort to traditional healthcare and only go to chemist shops when traditional health healers fail (Aragaw et al. 2020; Mothibe and Sibanda, 2018) This does not help marketing of orthodox healthcare products following this high level of dependence and view on traditional health healers compared to orthodox healthcare.

Besides negligence of immunisation, and dependence on traditional health healers as the main determinants of marketing of healthcare products, the study established some other dilemmas to be determinants of marketing of healthcare products. These cultural dilemmas include rejection of western medicine, family spiritual beliefs, lack of openness to questions from healthcare practitioners, perception of illness, influence of family dynamics, willingness to discuss symptoms with health providers, and access to needed healthcare resources for the aged. Though these dilemmas posed lesser influence compared to negligence of immunisation, and dependence on traditional healthcare healers, they are still important considerations in determining marketing of healthcare products. However, the major cultural factor at the heart of these dilemmas is education and formal learning. This factor among other factors of lesser influence such as opinions, learning experiences, gender, food and dietary beliefs, religion and family setting play determinant roles in influencing marketing of healthcare products.

Concerning ethical dilemmas, maintaining ethical work environment is the major determinant of marketing of healthcare products. Ethical issues are great concerns in marketing of products. The result of the study explains this with positive mean results of the statements associated with marketing of healthcare products. Maintenance of good ethical work environment is paramount in healthcare products and this is buttressed by the study. Other dilemmas of lesser influence on marketing of healthcare products are conflict of interest between health practitioners, moral distress and resilience, incompetence among health providers, telemedicine, treating disadvantaged patients, physician-assisted deaths, and wrestling with equal treatment to average patients versus VIP treatment to donors and influential individuals. On the other hand, ethical norms play important role in ethical dilemmas that affect marketing of healthcare products. Mislabelling of healthcare products, counterfeit healthcare products, and unregistered healthcare products are peculiar ethical concerns on products. They are the moral concerns people have on healthcare products. In addition, excessive mark up, general honesty and integrity of healthcare products, and illegal importation are as well very important ethical norms that influences ethical dilemma on marketing of healthcare products.

Generally, cultural and ethical dilemmas influence marketing of healthcare products. The most important ones that marketers and firms should critically focus on are negligence of immunisation, dependence on traditional health healers, and maintenance of ethical work environment. By implication, marketing of healthcare products will greatly face challenges following these dilemmas customers have in patronising orthodox healthcare facilities and products. The interesting point about this research that customers have different cultural and ethical dilemmas as well as norms however, not all of them have equal influence on marketing of healthcare products. While marketers may be tempted to neglect the influences of the dilemmas with lesser influence, the patronage of healthcare products will definitely be affected. The study's result points out practically shows that cultural and ethical dilemmas influencing marketing of healthcare products can be grouped into major ones and lesser ones though both are not supposed to be neglected when designing marketing programmes.

Contributions and Implications. Although cultural and ethical dilemmas are not a current emergence in literature and academia, they have often been given less attention with respect to how they influence 

Healthcare Products

the marketing of products. The study highlighted several cultural and ethical dilemmas customers have in patronising healthcare products however these dilemmas appear in two groups of effects. Those with greater influence were termed «higher effects» while the ones with lesser influence were termed «lesser effects». On the other hand, understanding the peculiarity of cultural and ethical dilemmas with respect to specific societies will be very useful for marketing firms and marketers in designing marketing programmes and formulating strategies that will promote sales and patronage.

The results obtained from this study clearly underline the need to make efforts in dousing the fears and stereotypes associated with orthodox healthcare products. In addition, the result implies that there is need for education, learning and awareness campaigns on orthodox effectiveness in treating health issues. Cultural norms of indigenous people may be challenging to modify, especially on cases where all health concerns are associated with spiritual problems, making them classify orthodox healthcare as a last resort. However, culture can be modified on the long run. The result implies that through appropriate education, sensitisation, and sale of original orthodox healthcare products, cultural and ethical dilemmas on healthcare products as well as cultural factors militating against marketing of healthcare products will change.

Moreover, the study's context indicates in-group factors like family opinions, and the group the indigenous people belong to has a prevailing control on healthcare products. Precisely, this informs that marketing firms need to strategically position themselves to the families, relatives, and the in-group of a customer to reduce dilemmas and positively affect marketing of their healthcare products.

The study had some limitations. The selected sample covered only people from eastern Nigeria who possibly have the profile of falling within the category of the theory of collectivism. This could result in distorted results when compared with inclusions of other parts of the country. Thus, enlarging the sample to include respondents from other cultural divide in the country could present better representativeness. The results of the study were analysed using mean analysis and correlation coefficient. In this regard, there could be problems in extrapolated conclusions. In essence, there are salient areas or further studies. Notably, it includes assessing the effectiveness of existing policies on traditional medicine against the cultural factors moderating health behavior of indigenous people. Cross-sectional research is also recommended on the concurrent use of orthodox and traditional medicine by indigenous people particularly in developing nations.

Author Contributions: conceptualization, U. O. O. J. and A. O.; methodology, U. O., A. O. and O. O.; software validation, O. O. and O. J.; formal analysis, U. O.; investigation, O. O.; resources, O. J.; data curation, A. O.; writing original draft preparation, O. J.; writing review and editing, A. O.; visualization, O. O.; supervision, U. O.; project administration, U. O. and O. O.

Funding: This research did not receive any funding.

\section{Reference}

Afolabi, F. J., De Beer, P., \& Haafkens, J. A. (2020). Orthodox or traditional medicine? Private or public healthcare? Exploring treatment pathways for occupational health problems among informal automobile artisans. Social Science \& Medicine, 265, 113510. [Google Scholar] [CrossRef]

Ahlberg, B. M. (2017). Integrated health care systems and indigenous medicine: reflections from the sub-sahara African region. Frontiers in Sociology, 2, 12. [Google Scholar] [CrossRef]

Ajima, O. G., \& Ubana, E. U. (2018). The concept of health and wholeness in traditional African religion and social medicine, Arts and Social Sciences Journal, 9(4), 2-5. [Google Scholar]

Akosah-Twumasi, P., Emeto, T. I., Lindsay, D., Tsey, K., \& Malau-Aduli, B. S. (2018). A systematic review of factors that influence youths career choices-the role of culture. In Frontiers in Education (Vol. 3, p. 58). Frontiers. [Google Scholar] [CrossRef]

Ali, S. W., \& Sudan, S. (2018). Influence of cultural factors on impulse buying tendency: A study of Indian consumers. Vision, 22(1), 68-77. [Google Scholar] [CrossRef] 
Ameade, E. P. K., Ibrahim, M., Ibrahim, H. S., Habib, R. H., \& Gbedema, S. Y. (2018). Concurrent use of herbal and orthodox medicines among residents of Tamale, Northern Ghana, who patronize hospitals and herbal clinics. Evidence-Based Complementary and Alternative Medicine, 2018. [Google Scholar] [CrossRef]

Aragaw, T. J., Afework, D. T., \& Getahun, K. A. (2020). Assessment of knowledge, attitude, and utilization of traditional medicine among the communities of Debre Tabor Town, Amhara Regional State, North Central Ethiopia: A cross-sectional study. EvidenceBased Complementary and Alternative Medicine, 2020. [Google Scholar] [CrossRef]

Asakitikpi, A. E. (2019). Healthcare coverage and affordability in Nigeria: an alternative model to equitable healthcare delivery. In Universal Health Coverage (p. 45). London, UK: IntechOpen. [Google Scholar] []

Asioli, D., Aschemann-Witzel, J., Caputo, V., Vecchio, R., Annunziata, A., Næs, T., \& Varela, P. (2017). Making sense of the "clean label" trends: A review of consumer food choice behavior and discussion of industry implications. Food Research International, 99, 58-71. [Google Scholar] [CrossRef]

Bairagdar, N., Reich, A., \& Franck, J. B. (2021). Impact of marketing to improve patient access to care and clinic utilization for clinical pharmacy specialists. Mental Health Clinician, 11(2), 59-63. [Google Scholar] [CrossRef]

Bettels, J., \& Wiedmann, K. P. (2019). Brand logo symmetry and product design: The spillover effects on consumer inferences. Journal of Business Research, 97, 1-9. [Google Scholar] [CrossRef]

Bissessar, C. (2018). An application of Hofstede's cultural dimension among female educational leaders. Education sciences, 8(2), 77. [Google Scholar] [CrossRef]

Biswal, R., Subudhi, C., \& Acharya, S. K. (2017). Healers and healing practices of mental illness in India: The role of proposed eclectic healing model. Journal of Health Research and Reviews, 4(3), 89. [Google Scholar] [CrossRef]

Boca, G. D. (2021). Factors influencing consumer behavior in sustainable fruit and vegetable consumption in maramures county, Romania. Sustainability, 13(4), 1812. [Google Scholar] [CrossRef]

Budhathoki, P. (2019). The Gap between Attitudes and Behavior in Ethical Consumption: A Critical Discourse. Budhathoki, P., Adhikari, K., \& Koirala, 285-295. [Google Scholar] CrossRef]

Burnett, K., Sanders, C., Halperin, D., \& Halperin, S. (2020). Indigenous Peoples, settler colonialism, and access to health care in rural and northern Ontario. Health \& Place, 66, 102445. [Google Scholar] [CrossRef]

Castro, R., \& Sáiz, P. (2020). Cross-cultural factors in international branding. Business History, 62(1), 1-25. [Google Scholar] [CrossRef]

Chegini, F., Molan, S. B., \& Kashanifar, S. S. (2016). An examination of the impact of cultural values on brand preferences in Tehran's Fashion Market. Procedia Economics and Finance, 36, 189-200. [Google Scholar] [CrossRef]

Dahia, P. D., \& Chima, P. (2017). Social-Economic and Cultural Barriers and Primary Health Care Service Delivery in Rural Communities in Abuja, Nigeria. Journal of Social Sciences (COES\&RJ-JSS), 6(2), 413-423. [Google Scholar] [CrossRef].

de Graaf, F. J. (2019). Ethics and behavioural theory: how do professionals assess their mental models?. Journal of Business Ethics, 157(4), 933-947. [Google Scholar] [CrossRef].

Ekiyor, A., \& Altan, F. (2020). Marketing Communication and Promotion in Health Services. In Promotion and Marketing Communications. IntechOpen. [Google Scholar]

European Health Report. (2018). Capturing the Health 2020 Core Values. Retrieved from [Link]

Faasse, K., \& Newby, J. (2020). Public perceptions of COVID-19 in Australia: Perceived risk, knowledge, health-protective behaviors, and vaccine intentions. Frontiers in Psychology, 11. [Google Scholar] [CrossRef]

Fadyl, J. K. (2021). How can societal culture and values influence health and rehabilitation outcomes? Expert Review of Pharmacoeconomics \& Outcomes Research, 21(1), 5-8. [Google Scholar] [CrossRef]

Figar, N., \& Dordevic, B. (2016). Managing an ethical dilemma. Economic Themes, 54(3), 345-362. [Google Scholar] [CrossRef] Gravesande, J., Richardson, J., Griffith, L., \& Scott, F. (2019). Test-retest reliability, internal consistency, construct validity and factor structure of a falls risk perception questionnaire in older adults with type 2 diabetes mellitus: a prospective cohort study. Archives of physiotherapy, 9(1), 1-11. [Google Scholar] [CrossRef]

Greif, A. (2006). Institutions and the path to the modern economy: Lessons from medieval trade. Cambridge University Press. [Google Scholar]

Hair, F. J., Black, C. W., Babin, J. B., Anderson, E. R., \& Tatham, L. R. (2006). Multivariate Data Analysis (6th ed). New Jersey: Pearson Educational International.

Hédoin, C. (2021). The Beliefs-Rules-Equilibrium Account of Institutions: A Contribution to a Naturalistic Social Ontology. Journal of Social Ontology. [Google Scholar] [CrossRef] Hernandez, M., \& Gibb, J. K. (2020). Culture, behavior and health. Evolution, medicine, and public health, 2020(1), 12-13. [Google Scholar] [CrossRef]

Heward-Mills, N. L., Atuhaire, C., Spoors, C., Pemunta, N. V., Priebe, G., \& Cumber, S. N. (2018). The role of faith leaders in influencing health behaviour: a qualitative exploration on the views of Black African Christians in Leeds, United Kingdom. The Pan African Medical Journal, 30. [Google Scholar] [CrossRef]

Hofstede, G. (2011). Dimensionalizing cultures: The Hofstede model in context. Online readings in psychology and culture, 2(1), 2307-0919. [Google Scholar] [CrossRef]

Hofstede, G., Hofstede, J. G., \& Minkov, M. (2010). Cultures and Organizations: Software of the Mind (3rd ed). New York: McGraw-Hill. [Google Scholar] 
O. U., Oteh, A. O., Oloveze, R. O., Obasi, J. O., Opara. Consumer Health Knowledge: Cultural Norms and Marketing of Healthcare Products

Hussain, A., Ali, S., Ahmed, M., \& Hussain, S. (2018). The anti-vaccination movement: a regression in modern medicine. Cureus, 10(7). [Google Scholar] [CrossRef]

Kahissay, M. H., Fenta, T. G., \& Boon, H. (2017). Beliefs and perception of ill-health causation: a socio-cultural qualitative study in rural North-Eastern Ethiopia. BMC public health, 17(1), 1-10. [Google Scholar] [CrossRef]

Kahissay, M. H., Fenta, T. G., \& Boon, H. (2020). Religion, spirits, human agents and healing: A conceptual understanding from a sociocultural study of Tehuledere Community, Northeastern Ethiopia. Journal of religion and health, 59(2), 946-960. [Google Scholar] [CrossRef]

Kaihlanen, A. M., Hietapakka, L., \& Heponiemi, T. (2019). Increasing cultural awareness: qualitative study of nurses' perceptions about cultural competence training. BMC nursing, 18(1), 1-9. [Google Scholar] [CrossRef

Kaur, J., \& Chawla, R. (2016). Impact of Culture on Marketing Strategies.Imperial Journal of Interdisciplinary Research, 2(3) $325-330$

Kawakami, N., Thi Thu Tran, T. Watanabe, K., Imamura, K., Thanh Nguyen, H., Sasaki, N., Kuribayashi, K., Sakuraya, A. Thuy Nguyen, Q. ... \& Tsutsumi, A. (2020). Internal consistency reliability, construct validity, and item response characteristics of the Kessler 6 scale among hospital nurses in Vietnam. PLoS ONE, 15(5). [CrossRef]

Khan, M. A., \& Law, L. S. (2018). The role of national cultures in shaping the corporate management cultures: A three-country theoretical analysis. Organizational Culture. [Google Scholar] [CrossRef]

Klantschnig, G., \& Huang, C. (2019). Fake drugs: health, wealth and regulation in Nigeria. Review of African Political Economy, 46(161), 442-458. [Google Scholar] [CrossRef]

Krah, E., de Kruij, J., \& Ragno, L. (2018). Integrating traditional healers into the health care system: challenges and opportunities in rural northern Ghana. Journal of Community Health, 43(1), 157-163. [Google Scholar] [CrossRef]

Kraus, A., Annunziata, A., \& Vecchio, R. (2017). Sociodemographic factors differentiating the consumer and the motivations for functional food consumption. Journal of the American College of Nutrition, 36(2), 116-126. [Google Scholar] [CrossRef]

Latif, A. S. (2020). The importance of understanding social and cultural norms in delivering quality health care-A personal experience commentary. Tropical medicine and infectious disease, 5(1), 22. [Google Scholar] [CrossRef]

Li, J. B., T. Vazsonyi, A., \& Dou, K. (2018). Is individualism-collectivism associated with self-control? Evidence from Chinese and US samples. PloS one, 13(12). [Google Scholar] [CrossRef

Liao, C. H. (2020). Evaluating the Social Marketing Success Criteria in Health Promotion: A F-DEMATEL Approach. International journal of environmental research and public health, 17(17), 6317. [Google Scholar] [CrossRef]

Liu, Y., \& Segev, S. (2017). Cultural orientations and environmental sustainability in households: A comparative analysis of Hispanics and non-Hispanic Whites in the United States. International Journal of Consumer Studies, 41(6), 587-596. [Google Scholar] [CrossRef

Luo, Y., Yao, L., Zhou, L., Yuan, F., \& Zhong, X. (2020). Factors influencing health behaviours during the coronavirus disease 2019 outbreak in China: an extended information-motivation-behaviour skills model. Public Health, 185, 298-305. [Google Scholar] CrossRef

Mordeniz, C. (2019). Introductory Chapter: Traditional and Complementary Medicine. Traditional and Complementary Medicine, 1-21. [Google Scholar]

Mothibe, M. E., \& Sibanda, M. (2019). African traditional medicine: South African perspective. Traditional and Complementary Medicine, 1-27. [Google Scholar] [CrossRef]

Mumley, W. E. (2019). Organizational culture and ethical decision-making during major crises. The Journal of Values-Based Leadership, 12(2), 9. [Google Scholar] [CrossRef

National Bureau of Statistics. (2011). Nigeria: Monitoring the situation of children and women. Nigeria Multiple Indicator Cluster Survey 2011 Summary Report. Retrieved from [Link]

Nguyen, T. T. M., Phan, T. H., Nguyen, H. L., Dang, T. K. T., \& Nguyen, N. D. (2019). Antecedents of purchase intention toward organic food in an asian emerging market: A study of urban vietnamese consumers. Sustainability, 11(17), 4773. [Google Scholar] [CrossRef]

Ngwenya, N., Nkosi, B., Mchunu, L. S., Ferguson, J., Seeley, J., \& Doyle, A. M. (2020). Behavioural and socio-ecological factors that influence access and utilisation of health services by young people living in rural KwaZulu-Natal, South Africa: Implications for intervention. PloS one, 15(4), e0231080. [Google Scholar] [CrossRef]

Odwe, G., Ndwiga, C., Okondo, C., Sripad, P., Abuya, T., \& Warren, C. E. (2020). Exploring communities' perceptions of the etiology of illnesses in newborns and young infants $0-59$ days old in 4 counties in Kenya. Plos one, 15(11), e0240852. [Google Scholar] [CrossRef]

Ofurum, U. A., \& Gabriel, J. M. O. (2019). Multidimensional Ethical Dilemmas of Contemporary Organizations: A Literature Review. International Journal of Innovation and Economic Development, 5(3), 7-18. [Google Scholar] [CrossRef]

Ojua, T., Ishor, D., \& Ndom, P. (2013). African cultural practices and health implications for Nigeria rural development. International review of management and business research, 2(1). [Google Scholar]

Oloveze, A. O., Oteh, O. U., Nwosu, H. E., \& Obasi, R. O. (2021). How user behaviour is moderated by affective commitment on point of sale terminal. Rajagiri Management Journal. [Google Scholar] 
Oteh, U. O., Nduka, C., \& Oteh, C. (2016). Deepening Insurance Penetration and Marketing: Demographic Factors and Healthcare Insurance Acceptability among Rural People in Abia State, Nigeria. Funai Journal of Humanities and Social Sciences, 3(1), 30-45. [Google Scholar]

Papazoglou, G. E. (2019). Society and Culture: Cultural Policies Driven by Local Authorities as A Factor in Local DevelopmentThe Example of the Municipality of Xanthi-Greece. Heritage, 2(3), 2625-2639. [Google Scholar] [CrossRef]

Paudel, U. R., Devkota, N., \& Bhandari, U. (2018). Socio-cultural and economic factors in cross-border purchase: A study of customers' perspective in Sunauli-Nepal/India Border. Modern Economy, 9(06), 1089. [Google Scholar] [CrossRef]

Peprah, P., Gyasi, R. M., Adjei, P. O. W., Agyemang-Duah, W., Abalo, E. M., \& Kotei, J. N. A. (2018). Religion and Health: exploration of attitudes and health perceptions of faith healing users in urban Ghana. BMC public health, 18(1), 1-12. [Google Scholar] [CrossRef

Pfeiffer, J., Li, H., Martez, M., \& Gillespie, T. (2018). The role of religious behavior in health self-management: A communitybased participatory research study. Religions, 9(11), 357. [Google Scholar] [CrossRef]

Poorchangizi, B., Borhani, F., Abbaszadeh, A., Mirzaee, M., \& Farokhzadian, J. (2019). The importance of professional values from nursing students' perspective. BMC nursing, 18(1), 1-7. [Google Scholar] [CrossRef]

Popovic, I., Bossink, B. A., \& van der Sijde, P. C. (2019). Factors Influencing Consumers' Decision to Purchase Food in Environmentally Friendly Packaging: What Do We Know and Where Do We Go from Here?. Sustainability, 11(24), 7197. [Google Scholar] [CrossRef]

Prinsloo, C., \& Lew, C. (2021). Openness to change and conservation in value-laden decisions. SA Journal of Human Resource Management, 19, 11. [Google Scholar] [CrossRef]

Purcarea, E. V. L. (2019). The impact of marketing strategies in healthcare systems. Journal of medicine and life, 12(2), 93. [Google Scholar] [CrossRef]

Rana, J., \& Paul, J. (2017), Consumer behavior and purchase intention for organic food: A review and research agenda. Journal of Retailing and Consumer Services, 38, 157-165. [CrossRef]

Rokeach, M. (1973). The nature of human values. Free press. [Google Scholar]

Saidi, S. S., \& Siew, N. M. (2019). Investigating the Validity and Reliability of Survey Attitude towards Statistics Instrument among Rural Secondary School Students. International Journal of Educational Methodology, 5(4), 651-661. [Google Scholar] [CrossRef]

Salim, I., Mohammed, M., Khalid, G. M., Tijjani, N. A., Yaro, A. H., \& Maiha, B. B. (2018). Concurrent use of orthodox and herbal antimalarials among science-based undergraduate students of Ahmadu Bello University, Nigeria. Bayero Journal of Pure and Applied Sciences, 11(1), 465-470. [Google Scholar] [CrossRef]

Sama, R. (2019). Impact of media advertisements on consumer behaviour. Journal of Creative Communications, 14(1), 54-68. [Google Scholar] [CrossRef]

Saunders, M., Lewis, P., \& Thornhill, A. (2009). Research methods for business students. Pearson education. [Google Scholar] Seshan, V., Alkhasawneh, E., Al Kindi, S., \& Abdel-Majid, F. (2018). Can Gestational Anemia be Alleviated with Increased Awareness of its Causes and Management Strategies? Implications for Health Care Services. Oman Medical Journal, 33(4), 322330. [Google Scholar]

Shahin, W., Kennedy, G. A., \& Stupans, I. (2019). The impact of personal and cultural beliefs on medication adherence of patients with chronic illnesses: a systematic review. Patient preference and adherence, 13, 1019. [Google Scholar] [CrossRef]

Silas, J., Mamman, M., Leah, G. J., \& Yusuf, O. R. (2015). An Examination of the Perception and Patronage of Traditional Medicine in Kaduna State, Nigeria. International Journal of Advancements in Research \& Technology, 4(11), 1-19.

Singh, A., Divate, V., Khare, S., Raut, R., \& Rathod, M. (2020). How Does Culture Affect Consumer Buying Behaviour? International Journal for Research in Engineering Application \& Management (IJREAM), 6(4), 111-113.

Song, R., Moon, S., Chen, H. A., \& Houston, M. B. (2017). When marketing strategy meets culture: the role of culture in product evaluations. Journal of the Academy of Marketing Science, 46(3), 384-402. [Google Scholar] [CrossRef]

Sorum, N. (2020). Ethical consumption applications as failed market innovations: exploring consumer (non) acceptance of 'quasi'market devices. Journal of Cultural Economy, 13(1), 91-113. [Google Scholar] [CrossRef]

Stokhof, M. J. B. (2018). Ethics and morality, principles and practice. Zeitschrift für Ethik und Moralphilosophie, 1(2), 291-304. [Google Scholar] [CrossRef]

Tamunomiebi, M. D., \& Ehior, I. E. (2019). Diversity and ethical issues in the organizations. International Journal of Academic Research in Business and Social Sciences, 9 (2), 839-864. [Google Scholar]

Van Rooij, B., \& Fine, A. (2018). Toxic corporate culture: assessing organizational processes of deviancy. Administrative Sciences, 8(3), 23. [Google Scholar] [CrossRef]

Verboord, M., \& Nørgaard Kristensen, N. (2020). EU cultural policy and audience perspectives: how cultural value orientations are related to media usage and country context. International Journal of Cultural Policy, 1-16. [Google Scholar] [CrossRef]

Von Helversen, B., Abramczuk, K., Kopec, W., \& Nielek, R. (2018). Influence of consumer reviews on online purchasing decisions in older and younger adults. Decision Support Systems, 113, 1-10. [Google Scholar] [CrossRef]

Workneh, T., Emirie, G., Kaba, M., Mekonnen, Y., \& Kloos, H. (2018). Perceptions of health and illness among the Konso people of southwestern Ethiopia: persistence and change. Journal of ethnobiology and ethnomedicine, 14(1), 1-9. [Google Scholar] [CrossRef 
O. U., Oteh, A. O., Oloveze, R. O., Obasi, J. O., Opara. Consumer Health Knowledge: Cultural Norms and Marketing of Healthcare Products

World Bank. (2013). World Development Indicators. Retrieved from [Link]

World Health Organisation. (2005). Nutrition in adolescence: Issues and Challenges for the Health Sector, Issues in Adolescent Health and Development, WHO Discussion Papers on Adolescence, NSL Classification: WS 115. Retrieved from [Link]

Огбонна Уке Отех, Ph.D., Сільськогосподарський університет імені Майкла Окпара Умудіке (Нігерія)

Амвросій Огбонна Оловезе, Сільськогосподарський університет імені Майкла Окпара Умудіке (Нігерія);

Раймонд Озоємена Обасі, Ph.D., Сільськогосподарський університет імені Майкла Окпара Умудіке (Нігерія);

Джастін O. Опара, Сільськогосподарський університет імені Майкла Окпара Умудіке (Нігерія)

Знання про здоров'я споживачів: культурні норми та маркетинг медичних товарів

Об'єктом дослідження є продукти охорони здоров'я, зокрема специфрічні культурні дилеми та етичні проблеми, пов'язані з ними. Метою статті є оцінювання знань про здоров'я споживачів з урахуванням явища культурно-етично дилеми та норм, що впливає на маркетинг здорових продуктів. Ті дилеми, що мають більший вплив мають «вищий ефект», а ті, що менший вплив, - «меншиий ефект». Аналіз літературних джерел вказує на існування помилкових уявлень та низькі показники збуту таких продуктів у культурному середовищі Нігерії. Незважаючи на те, що культурноетичні дилеми є важливими у маркетингу продуктів, їм приділяють не достатньо уваги. Для узагальнення знань про здоров'я споживачів авторами змодельовано вимір колективізму Хофостеде. Вирішення наукових питань дозволить реструктуризвувати підходи до побудови комунікацій виробників медичних продуктів. Польове дослідження проводилося у вигляді опитування. Дані збиралися впродовж 4-5 місяиів у 2020 році за допомогою структурованої анкети. Для аналізу результатів використаний середній рейтинговий аналз та кореляція Пірсона. Географія дослідження - штат Абіа в Нігерії. Результати дослідження показали, що негативне ставлення до імунізації, залежність від цілителів та підтримка прийнятного етичного робочого середовища є критично важливими проблемами, які впливають на обізнаність про різні аспекти здоров'я серед споживачів та на їх реакцію на товари, що пропонуються різними компаніями. Авторами емпірично підтверджено і теоретично доведено, що вимір колективізму Хофостеде належним чином відображає домінуючий культурний контекст у групі корінного населення штату Абіа в Нігерії. Результати проведеного дослідження мають практичну цінність, оскільки допомагають у майбутньому виявляти потреби в спілкуванні, програмах просвіти серед населення. Також автори описують практичні вимоги до стратегічних підходів у маркетингу здорових продуктів у громадах. Розуміння особливостей культурно-етичних дилер у конкретному суспільстві $\epsilon$ необхідним для компаній, що працюють у ссфері маркетингу та для фрахівців, що займаються розробленням маркетингових програм та формуванням стратегій, що сприяють збуту здорових продуктів.

Ключові слова: колективізм, знання про здоров'я споживачів, культурна дилема, етичні норми, продукти охорони здоров'я, маркетинг. 